\title{
ANALISIS KESALAHAN MENYUSUN KALIMAT BAHASA JERMAN
}

\author{
Herlin $^{1}$, Laelah Azizah ${ }^{2}$, dan Syarifah Fathimah A. I ${ }^{3}$ \\ Fakultas Bahasa dan Sastra, Universitas Negeri Makassar \\ Email: herlinresia@gmail.com ${ }^{1}$
}

\begin{abstract}
ABSTRAK
Tujuan penelitian ini adalah untuk memeroleh data dan informasi mengenai kesalahan dan persentase kesalahan siswa dalam menyusun kalimat bahasa Jerman. Desain penelitian yang digunakan dalam penelitian ini adalah metode deskriptif. Untuk menganalis data digunakan rumus teknik persentase dan dalam pengumpulan data digunakan tes tertulis untuk mengetahui kesalahan siswa dalam kalimat berita bahasa Jerman, kalimat tanya bahasa Jerman dan kalimat perintah bahasa Jerman. Hasil penelitian ini menunjukkan bahwa, kesalahan menyusun kalimat berita bahasa Jerman 33.03\%, kesalahan menyusun kalimat tanya bahasa Jerman $42.55 \%$ dan kesalahan menyusun kalimat perintah bahasa Jerman $49.52 \%$.
\end{abstract}

Kata Kunci: Analisis Kesalahan Berbahasa, Bahasa Jerman, Kalimat.

\begin{abstract}
The purpose of this study was to obtain data and information about errors and percentage of students' errors in composing German sentences. The research design used in this study is descriptive method. To analyze the data used the percentage technical formula and in the data collection used a written test to determine students' errors in German language sentences, German question sentences and German command sentences. The results of this study indicate that, errors in composing German language news sentences $33.03 \%$, errors in composing German question sentences $42.55 \%$ and errors in composing German command sentences $49.52 \%$.
\end{abstract}

Keywords: Error Analysis, German Language, Sentence.

\section{PENDAHULUAN}

Pembelajaran bahasa asing saat ini merupakan kebutuhan yang harus dimiliki seseorang. Dengan penguasaan bahasa asing diharapkan seseorang dapat meningkatkan kompetensi berbahasa yang dimilikinya. Mengingat saat ini Indonesia telah banyak membangun kerja sama dengan negaranegara maju dan berkembang lainnya. Oleh karena itu, di berbagai lembaga pendidikan di Indonesia selain diajarkan bahasa daerah dan bahasa Indonesia diajarkan pula bahasa asing. Salah satu bahasa asing yang dipelajari adalah bahasa Jerman yang telah dimasukkan dalam kurikulum beberapa Sekolah Menengah Atas (SMA).

Kedudukan bahasa Jerman sebagai salah satu bahasa yang banyak digunakan di dunia mengharuskan pembelajar untuk mengetahui, memahami, ataupun mendalami bahasa Jerman. Oleh karena itu, para pelajar dituntut untuk mengetahui bahasa Jerman 
dengan baik. Mengingat Jerman adalah salah satu negara maju yang paling banyak menanamkan investasi di Indonesia, selain itu Jerman juga merupakan negara yang memberikan kesempatan bagi para pelajar di dunia untuk belajar di Jerman. Indonesia dan Jerman menjalin kerja sama bukan hanya di bidang ilmu pengetahuan dan teknologi, ekonomi, sosial dan budaya, tetapi juga dalam bidang pendidikan. Berbagai bentuk kerja sama yang telah dilakukan, salah satunya adalah berbagai tawaran beasiswa kepada pelajar Indonesia oleh pemerintah Jerman. Hal ini tentunya sangat menguntungkan bagi Indonesia sebagai negara yang dalam masa perkembangan untuk meningkatkan sumber daya dalam menghadapi persaingan global. Oleh karena itu, bahasa Jerman telah diajarkan di sekolahsekolah di Indonesia secara formal pada jenjang pendidikan menengah seperti SMA/SMK dan MA.

Pada dasarnya dalam pembelajaran bahasa Jerman terdapat empat kompetensi berbahasa yang diajarkan, yaitu: kemampuan menyimak (Hörverstehen), keterampilan berbicara (Sprechfertigkeit), kemampuan membaca (Leseverstehen), dan keterampilan menulis (Schreibfertigkeit), serta ditunjang dua aspek kemampuan, yaitu: tata bahasa (Gramatik) dan kosakata (Wortschatz). Oleh karena itu, siswa diharapkan mampu menguasai kompetensi berbahasa tersebut baik secara teori maupun praktek, dimana siswa tidak hanya mampu memahami materi dari keempat keterampilan tersebut, melainkan dapat menerapkannya dalam kehidupan sehari- hari.

Studi pada pembelajar bahasa Jerman telah banyak dilakukan oleh peneliti-peneliti sebelumnya. (Qalbi et all, 2017; Quddus et all, 2017; Mantasiah et all, 2018; 2017).
Penelitian-penelitian tersebut mengkaji baik dari aspek morfologi, sintaksis atapun dalam aspek wacana. Salah satu aspek yang penting untuk dikaji adalah aspek kalimat. Kemampuan menyusun kalimat tidak terlepas dari penguasaan tata bahasa seseorang. Tata bahasa merupakan dasar bahasa dan untuk menyusun kalimat yang baik haruslah dipahami tata bahasanya. Begitu pula terhadap kosa kata, karena tanpa kosa kata yang memadai seseorang tidak dapat menggunakan suatu bahasa dengan baik. Oleh karena itu pada proses belajar mengajar bahasa Jerman di sekolah keempat kompetensi dan kemampuan tersebut di atas diajarkan secara terpadu atau integratif. Menyusun kalimat bahasa Jerman merupakan hal yang penting untuk diajarkan. Dikatakan penting, karena tingkat keterampilan menulis siswa tidak hanya diukur dari segi menulis lambang-lambang huruf saja, melainkan juga diukur dari segi kemampuan siswa menempatkan kata-kata ke dalam kalimat dengan baik sesuai dengan pola tata bahasa Jerman. Oleh sebab itu, semakin baik penguasaan tata bahasa dan kosakata siswa, akan semakin baik pula kemampuannya dalam menyusun kalimat.

Kesalahan-kesalahan yang sering dilakukan siswa disebabkan karena ketidakpahaman siswa mengenai aturan tata bahasa, kosakata yang kurang dikuasai, dan adanya kesalahan teknis. Hal ini dapat disebabkan karena siswa tidak memahami aspek-aspek tersebut dan langsung menerjemahkan kalimat yang disusun dalam bahasa Indonesia ke dalam bahasa Jerman, sehingga banyak menimbulkan kesalahan. Karya siswa pun hanya terkesan sebagai pemenuhan tugas semata. Hal tersebut sangat mempengaruhi perkembangan kemampuan penyusunan kalimat siswa, karena siswa akan 
sulit mengerti kaidah-kaidah dan tata bahasa dalam menyusun kalimat. Pada pembelajaran penyusunan kalimat guru sebaiknya melakukan evaluasi terhadap kalimat yang dibuat oleh siswa, dan memberikan latihan pada siswa agar mereka mengetahui sejauh mana kemampuan mereka dalam menyusun kalimat bahasa Jerman dan kesalahankesalahan apa saja yang dilakukan oleh mereka. Dengan demikian, siswa tidak lagi melakukan kesalahan yang sama selanjutnya.

Berdasarkan kurikulum 2006 yang harus dicapai oleh siswa dalam menyusun kalimat yaitu siswa mampu menyusun kata atau frasa menjadi kalimat dengan struktur yang tepat. Namun hasil wawancara dengan guru bahasa Jerman SMA Negeri 4 Watampone diperoleh data bahwa masih banyak siswa kelas XI Bahasa kurang mampu dalam menyusun kalimat bahasa Jerman, pernyataan ini diperkuat dari hasil ulangan akhir semester ganjil tahun ajaran 2016/2017 yang menunjukkan bahwa dari 34 siswa kelas XI Bahasa hanya 14 siswa yang mampu memenuhi Kriteria Kelulusan Minimum (KKM) yaitu 76. Hal ini disebabkan karena adanya perbedaan antara tata bahasa Jerman dengan tata bahasa Indonesia baik pada jenis, fungsi maupun penggunaannya. Pernyataan di atas didukung oleh hasil penelitian Magfiratunnisa (2011) yang menyimpulkan kesalahan siswa dalam menyusun kalimat tanya bahasa Jerman tergolong masih sangat tinggi yaitu $73,1 \%$, Jawa (2013) yang menyimpulkan bahwa kesalahan dalam menyusun kalimat berita bahasa Jerman juga masih sangat tinggi yaitu $75,74 \%$, dan juga hasil penelitian oleh Aruan (2012) yang menyimpulkan bahwa kesalahan dalam menulis karangan bahasa Jerman juga masih tinggi yaitu 55,75\%. Hal tersebutlah yang melandasi peneliti untuk mengkaji topik terkait analisis kesalahan dalam penyusunan kalimat bahasa Jerman pada siswa.

\section{METODE PENELITIAN}

Variabel dalam penelitian ini adalah variabel tunggal yaitu kesalahan siswa dalam menyusun kalimat bahasa Jerman. Penelitian ini merupakan penelitian deskriptif yakni menggambarkan secara objektif mengenai kesalahan-kesalahan yang dilakukan siswa dalam menyusun kalimat bahasa Jerman dalam kala Präsens. Penelitian analisis kesalahan berbahasa merupakan salah satu pendekatan dari linguistik terapan yang berusaha untuk mendeskripsikan kesulitankesulitan yang dialami oleh pembelajar (Jufri, 2017; Jufri, 2007; Yusri, 2016). Kesalahan-kesalahan yang dimaksud dalam penelitian ini adalah jenis kesalahan sintaksis yang mencakup kesalahan pola pembentukan kalimat berita, pola pembentukan kalimat tanya dan dan pola pembentukan kalimat perintah bahasa Jerman. Pada pengukuran variabel ini dilakukan dengan memberi tes menyusun kalimat bahasa Jerman. Tes ini dilakukan untuk mengetahui kesalahankesalahan yang dilakukan siswa dalam menyusun kalimat bahasa Jerman.

Adapun populasi dalam penelitian ini adalah siswa kelas XI Bahasa SMA Negeri 4 Watampone yang berjumlah 33 siswa. Instrumen yang digunakan dalam penelitian ini berbentuk tes tertulis. Tes tertulis yang diberikan terdiri atas tiga bagian yaitu menyusun kalimat dari kata-kata yang tersedia, menjadi kalimat berita, kalimat tanya, dan kalimat perintah bahasa Jerman dalam kala Präsens dengan memperhatikan konjugasi kata kerja sesuai subjek. Instrumen ini bertujuan untuk mengetahui kesalahankesalahan yang dilakukan siswa dalam menyusun kalimat bahasa Jerman. 
Pengumpulan data dalam penelitian ini dilakukan dengan memberikan tes tertulis kepada siswa berupa tes menyusun kata-kata acak dengan memperhatikan konjugasi kata kerja sesuai subjek menjadi sebuah kalimat bahasa Jerman dalam kala Präsens. Datadata yang diperoleh dalam penelitian ini dianalasis berdasarkan langkah-langkah analisis yaitu: (1) mengumpulkan sampel kesalahan, (2)mengidentifikasi dan mengelompokkan kesalahan, (3) Menghitung frekuensi kemunculan kesalahan, (4) Menjelaskan sifat kesalahan, penyebab terjadinya kesalahan dan cara mengatasi kesalahan. Adapun rumus yang digunakan dalam penelitian ini untuk mengetahui kesalahan siswa dalam menyusun kalimat bahasa Jerman adalah sebagai berikut:

Teknik Persentase: $\frac{n}{N} \mathrm{x} 100 \%$

\section{Keterangan:}

$\mathrm{n}=$ Jumlah kesalahan setiap aspek

$\mathrm{N}=$ Jumlah kesalahan seluruh aspek Sudjana (2008:67)

\section{HASIL DAN PEMBAHASAN}

Berikut ini akan diuraikan jenis-jenis kesalahan dan tingkat kesalahan yang dilakukan siswa kelas XI bahasa SMA Negeri 4 Watampone dalam menyusun kalimat berita, kalimat tanya, dan kalimat perintah bahasa Jerman. Untuk menandai kesalahan-kesalahan yang dilakukan oleh siswa maka digunakan simbol (*) yang ditempatkan pada awal kalimat.

\section{Kalimat Berita Bahasa Jerman}

\section{Kesalahan Konjugasi Kata Kerja}

Konjugasi merupakan perubahan kata kerja atau klasifikasi verba menurut infleksinya atau kala, persona, dan jumlah. Bentuk kata kerja dalam bahasa Jerman selalu mengalami perubahan bentuk berdasarkan subjeknya. Berikut ini merupakan contoh kesalahan konjugasi kata kerja yang dilakukan siswa dalam menyusun kalimat berita bahasa Jerman.

a. lesen-Zeitung-Nurul-eine.

Dalam data: * Nurul lest eine Zeitung.

Seharusnya: Nurul liest eine Zeitung.

b. aus- kommen-Mark Polen.

dalam data: * Mark kommen aus Polen.

Seharusnya: Mark kommt aus Polen.

Kesalahan yang dilakukan siswa pada kalimat $\left(a^{*}\right)$ di atas, karena siswa mengkonjugasi kata kerja lesen seperti kata kerja pada umumnya. Kata kerja lesen merupakan kata kerja kuat yang mengalami perubahan stamm, sehingga untuk subjek orang kedua tunggal $(d u)$ dan orang ketiga tunggal (er/sie/es) mengalami perubahan stamm kata kerja seperti pada perbaikan kalimat di atas. Sedangkan pada kalimat $\left(b^{*}\right)$ siswa tidak menyesuaikan subjek kalimat dengan kata kerja, subjek kalimat di atas yaitu Mark atau orang ketiga tunggal sehingga konjugasinya berakhiran $t$ seperti pada perbaikan kalimat di atas.

\section{Kesalahan Penempatan Kata Kerja}

Kesalahan penempatan kata kerja adalah salah satu kesalahan sintaksis, dimana kesalahan itu terletak pada kesalahan dalam menempatkan posisi kata kerja dalam sebuah kalimat berdasarkan kaidah bahasa yang berlaku dalam sebuah bahasa. Berikut ini merupakan contoh kesalahan penempatan kata kerja yang dilakukan siswa dalam menyusun kalimat berita bahasa Jerman.

a. Deutsch-jeden Tag-lernen-Ahmad.

Dalam data: *Jeden Tag Ahmad Deutsch lernen.

Seharusnya: Jeden Tag lernt Ahmad Deutsch.

b. aus-kommen-Mark-Polen.

Dalam data: *Mark aus kommt Polen. 
Seharusnya: Mark kommt aus Polen.

c. die-machen-Hausaufgabe-Nisa.

Dalam data: *Nisa die macht

Hausaufgabe.

Seharusnya: Nisa macht die

Hausaufgabe.

Pada kalimat $\left(a^{*}\right)$ siswa melakukan kesalahan karena menempatkan kata kerja pada akhir kalimat, dalam kaidah bahasa Jerman kata kerja selalu berada pada posisi setelah subjek kalimat atau berada pada sebelum subjek jika dalam bentuk inversi. Sedangkan pada kalimat (b*) dan (c*) siswa menempatkan kata kerja pada posisi ketiga dalam kalimat, pada kalimat (b*) siswa menempatkan kata kerja setelah preposisi, dan pada kalimat ( $\left.\mathrm{c}^{*}\right)$ siswa menempatkan kata kerja setelah artikel die.

\section{Kesalahan Penempatan Objek}

Kesalahan penempatan objek kalimat merupakan kesalahan sintaksis yang berkaitan dengan urutan penyusunan unsurunsur kalimat, dalam hal ini kesalahan menempatkan unsur objek dalam sebuah kalimat yang benar dan utuh berdasarkan tatabahasa sebuah bahasa. Di bawah ini merupakan contoh kesalahan penempatan objek yang dilakukan siswa dalam menyusun kalimat berita bahasa Jerman.

a. den Füller- Kollege- bringen- seinem-

Thomas.

Dalam data: *Thomas bringt den Füller seinem Kollege.

Seharusnya: Thomas bringt seinem

Kollege den Füller.

b. dem Madchen-ich-Buch-geben-ein.

Dalam data: *Ich gebe ein Buch dem

\section{Madchen.}

Seharusnya: Ich gebe dem Madchen ein Buch.

c. aus- kommen-Mark-Polen.

Dalam data: *Polen kommt aus Mark.
Seharusnya: Mark kommt aus Polen.

Kesalahan yang terjadi pada penempatan objek dalam kalimat (a*) dan (b*) di atas, karena siswa menyusun kalimat tersebut dengan menempatkan objek Akkusativ mendahului objek Dativ. Dalam struktur kalimat berita bahasa Jerman, apabila kalimat terdiri atas dua objek yakni Akkusativobjek dan Dativobjek, maka Dativobjek mendahului Akkusativobjek seperti pada perbaikan kalimat di atas. Sedangkan pada kalimat ( $\mathrm{c}^{*}$ ) kesalahan yang dilakukan siswa, karena siswa menempatkan kata Polen pada awal kalimat yang berfungsi sebagai subjek kalimat yang seharusnya menjadi objek kalimat.

\section{Kesalahan Penempatan Keterangan}

Kesalahan posisi keterangan adalah kesalahan dalam menempatkan kata keterangan. Kesalahan yang dimaksud adalah aturan peletakan kata keterangan dalam kalimat yaitu keterangan waktu atau keterangan tempat. Di bawah ini merupakan kesalahan posisi keterangan yang dilakukan siswa dalam menyusun kalimat berita bahasa Jerman.

a. Ilona- einen- im Sommer- machen- inDeutschland-Deutschkurs.

Dalam data: *Ilona macht einen im Sommer Deutschkurs in Deutschland.

Seharusnya: Im Sommer macht Ilona einen Deutschkurs in Deutschland.

b. Stellen- viele Bücher-das Zimmer-ichin.

Dalam data: *ich stelle das Zimmer in viele Bücher.

Seharusnya: In das Zimmer stelle ich viele Bücher.

Kesalahan yang terjadi pada posisi keterangan dalam kalimat $\left(a^{*}\right)$ dan $\left(b^{*}\right)$ di atas, karena siswa tidak memperhatikan aturan penempatan kata keterangan dalam 
kalimat. Penempatan yang benar dalam kaidah bahasa Jerman yaitu kata keterangan ditempatkan pada awal kalimat yang diikuti oleh kata kerja, sehingga kata kerja mendahului subjek kalimat seperti pada perbaikan kalimat di atas.

\section{Kesalahan Penempatan Artikel Kata Benda}

Kata benda dalam bahasa Jerman selalu dilekati dengan artikel yang berfungsi sebagai kata sandang. Artikel terletak sebelum kata benda, baik kata benda murni maupun kata benda yang berasal dari kata sifat dan kata kerja. Berikut ini merupakan kesalahan penempatan artikel kata benda yang dilakukan siswa dalam menyusun kalimat berita bahasa Jerman.

a. die-machen-Hausaufgabe-Nisa.

Dalam data: *Nisa die macht

Hausaufgabe.

Seharusnya: Nisa macht die

Hausaufgabe.

b. lesen-Zeitung-Nurul-eine.

Dalam data: *Nurul eine lest Zeitung.

Seharusnya: Nurul liest eine Zeitung.

c. den-mir-der Briefträger-geben-Brief.

Dalam data: *Der Briefträger geben den mir Brief.

Seharusnya: Der Briefträger gibt mir den Brief.

Kalimat $\left(a^{*}\right)$ di atas merupakan jenis bestimmter Artikel dalam bentuk Nominatif. Kesalahan yang terjadi pada penempatan artikel kata benda pada kalimat (a*) di atas, karena siswa menempatkan artikel kata benda tidak berdampingan dengan kata benda. Dalam struktur bahasa Jerman, kata benda selalu didahului dengan artikel baik dalam bentuk bestimmter Artikel maupun unbestimmter Artikel seperti pada perbaikan kalimat di atas. Adapun kalimat (b*) merupakan jenis unbestimmter Artikel, seperti kesalahan pada kalimat (a*), pada kalimat (b) siswa juga menempatkan artikel yang tidak berdampingan dengan kata benda. Sedangkan kalimat (c*) merupakan jenis artikel bestimmter Artikel dalam bentuk Akusatif . Pada kalimat (c*) kesalahan siswa juga karena penempatan artikel yang tidak berdampingan dengan kata benda seperti perbaikan kalimat di atas.

\section{Kesalahan Penempatan Preposisi}

Bahasa Jerman juga mengenal istilah Präpositionen atau kata depan. Kata depan digunakan untuk mengikuti keterangan tempat, dan keterangan waktu. Kata depan tersebut dapat digunakan sesuai jenis kasus yang dikenakan padanya.

Berikut ini merupakan kesalahan penempatan preposisi yang dilakukan siswa dalam menyusun kalimat berita bahasa Jerman.

a. aus- kommen-Mark-Polen.

Dalam data: *Mark aus kommt Polen.

Seharusnya: Mark kommt aus Polen.

b. stellen-viele Bücher-das Zimmer-ich-in.

Dalam data: *Ich stelle das Zimmer in viele Bücher.

Seharusnya: In das Zimmer stelle ich viele Bücher.

Kesalahan yang terjadi pada penempatan preposisi kalimat $\left(\mathrm{a}^{*}\right)$ dan $\left(\mathrm{b}^{*}\right)$ di atas, karena siswa menempatkan kata depan atau Präpositionen yang tidak beriringan dengan kata benda pada kalimat. Dalam struktur bahasa Jerman kata depan atau Präpositionen selalu diletakkan sebelum kata benda untuk mengikuti keterangan tempat atau keterangan waktu seperti pada perbaikan kalimat di atas.

\section{Kalimat Tanya Bahasa Jerman}

\section{Kesalahan Konjugasi Kata Kerja}

Bentuk kata kerja dalam bahasa Jerman selalu mengalami perubahan bentuk 
berdasarkan subjeknya. Berikut ini merupakan contoh kesalahan konjugasi kata kerja yang dilakukan siswa dalam menyusun kalimat tanya bahasa Jerman.

a. Fuad- einen- Vater- haben- noch?

Dalam data: *Habt Fuad noch einen Vater?

Seharusnya: Hat Fuad noch einen Vater?

b. Makassar-du-kommen-aus?

Dalam data: *Kommen du aus Makassar?

Seharusnya: Kommst du aus Makassar?

Pada kalimat $\left(a^{*}\right)$ di atas siswa mengkonjugasi kata kerja haben seperti kata kerja pada umumnya. Kata kerja haben jika bertemu dengan subjek orang kedua tunggal (du) dan subjek orang ketiga tunggal (er/sie/es) maka akan mengalami perubahan stamm yaitu dengan menghilangkan huruf $b$ seperti pada perbaikan kalimat di atas. Sedangkan pada kalimat (b*) siswa melakukan kesalahan karena tidak menyesuaikan subjek dengan kata kerja, subjek pada kalimat $\left(\mathrm{b}^{*}\right)$ di atas adalah $d u$ maka konjugasinya berakhiran st seperti pada perbaikan kalimat di atas.

\section{Kesalahan Penempatan Kata Tanya (W-Frage)}

Kesalahan penempatan kata tanya adalah salah satu kesalahan sintaksis, dimana kesalahan itu terletak pada kesalahan dalam menempatkan posisi kata tanya berdasarkan kaidah bahasa yang berlaku dalam sebuah bahasa. Berikut ini merupakan contoh kesalahan penempatan kata tanya yang dilakukan siswa dalam menyusun kalimat tanya bahasa Jerman.

a. ein Buch-kaufen- wann-Sie?

Dalam data: *Sie wann kaufen ein Buch?

Seharusnya: Wann kaufen Sie ein Buch?

b. gehen-warum- nicht-ihr?

Dalam data: *Ihr gehen nicht warum?

Seharusnya: Warum geht ihr nicht? c. Vater-was- machen-dein?

Dalam data: *Vater machen was dein?

Seharusnya: Was macht dein Vater?

Kesalahan yang terjadi pada penempatan kata tanya kalimat $\left(\mathrm{a}^{*}\right),\left(\mathrm{b}^{*}\right)$ dan $\left(\mathrm{c}^{*}\right)$ di atas, karena siswa menyusun kalimat tersebut dengan menempatkan kata tanya atau $w$-frage dengan tidak menempatkan kata tanya pada posisi pertama. Struktur kalimat tanya bahasa Jerman, apabila kalimat tanya tersebut dengan menggunakan kata tanya maka kata tanya ( $w$-frage) selalu berada pada posisi pertama dan diikuti kata kerja.

3. Kesalahan Penempatan Kata Kerja Pada Kalimat Tanya yang Tidak Menggunakan Kata Tanya (Eintscheidungsfragen)

Kesalahan penempatan kata kerja pada kalimat tanya yang tidak menggunakan kata tanya (Eintscheidungsfragen), dimana kesalahan itu terletak pada penempatan posisi kata kerja dalam kalimat tanya yang tidak menggunakan kata tanya (Eintscheidungsfragen). Berikut ini merupakan contoh kesalahan penempatan kata kerja pada kalimat tanya yang tidak menggunakan kata tanya (Eintscheidungsfragen) yang dilakukan siswa dalam menyusun kalimat tanya bahasa Jerman.

a. Makassar-du-kommen-aus?

Dalam data: *Du kommen aus
Makassar?

Seharusnya: Kommst du aus Makassar?

b. ein Buch-Jacob-bringen?

Dalam data: *Jacob bringt ein Buch?

Seharusnya: Bringt Jacob ein Buch?

Kesalahan yang terjadi pada kalimat $\left(a^{*}\right)$ dan $\left(b^{*}\right)$ di atas, karena siswa menyusun kalimat tersebut dengan menempatkan kata kerja pada posisi kedua. Struktur kalimat 


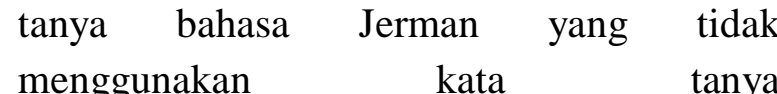
(Eintscheidungsfragen), maka kata kerja atau verba diletakkan di awal kalimat seperti pada perbaikan kalimat di atas.

\section{Kesalahan Penempatan Subjek}

Subjek atau pokok kalimat merupakan unsur utama dari sebuah kalimat. Subjek menentukan kejelasan makna sebuah kalimat, kesalahan penempatan subjek dapat mengaburkan makna dari sebuah kalimat. Dibawah ini merupakan contoh kesalahan penempatan subjek yang dilakukan siswa dalam menyusun kalimat tanya bahasa Jerman.

a. Makassar-du-kommen aus?

Dalam data: *Du kommen aus Makassar?

Seharusnya: Kommst du aus Makassar?

b. ein Buch-Jacob- bringen?

Dalam data: *Jacob bringt ein Buch?

Seharusnya: Bringt Jacob ein Buch?

c. ein Buch-kaufen-wann-Sie?

Dalam data: *Kaufen Sie wann ein Buch?

Seharusnya: Wann kaufen Sie ein Buch?

d. gehen- warum- ihr-nicht?

Dalam data: *Geht ihr warum nicht?

Seharusnya: Warum geht ihr nicht?

Kesalahan yang dilakukan siswa di atas terdiri dari kesalahan penempatan subjek pada kalimat tanya yang tidak menggunakan kata tanya (Eintscheidungsfragen) dan kalimat tanya yang menggunakan kata tanya (Bestimmungsfragen). Pada kalimat ( $\left.\mathrm{a}^{*}\right)$ dan (b*) siswa melakukan kesalahan penempatan subjek pada kalimat tanya yang tidak menggunakan kata tanya (Eintscheidungsfragen), dimana siswa menempatkan subjek kalimat pada posisi pertama. Aturan struktur kalimat tanya yang tidak menggunakan kata tanya (Eintscheidungsfragen) subjek ditempatkan pada posisi kedua atau setelah kata kerja yang berada pada posisi pertama seperti pada perbaikan kalimat di atas. Sedangkan pada kalimat $\left(c^{*}\right)$ dan $\left(d^{*}\right)$ merupakan kesalahan penempatan subjek kalimat tanya yang menggunakan kata tanya (Bestimmungsfragen), dimana siswa menempatkan subjek pada posisi kedua. Aturan stuktur kalimat tanya yang menggunakan kata tanya (Bestimmungsfragen) subjek ditempatkan pada posisi ketiga setelah kata tanya ( $w$ frage) dan kata kerja seperti pada perbaikan kalimat di atas.

\section{Kesalahan Penempatan Objek}

Kesalahan penempatan objek kalimat merupakan kesalahan sintaksis yang berkaitan dengan urutan penyusunan unsurunsur kalimat, dalam hal ini kesalahan menempatkan unsur objek dalam sebuah kalimat yang benar dan utuh berdasarkan tatabahasa sebuah bahasa. Di bawah ini merupakan contoh kesalahan penempatan objek yang dilakukan siswa dalam menyusun kalimat tanya bahasa Jerman.

a. Fuad- einen Vater- heben- noch?

Dalam data: *einen Vater noch haben Fuad?

Seharusnya: Hat Fuad noch einen Vater? b. ein Buch-kaufen- wann-Sie?

Dalam data: *Sie ein Buch wann kaufen? Seharusnya: Wann kaufen Sie ein Buch? Kesalahan yang terjadi pada penempatan objek kalimat $\left(a^{*}\right)$ dan $\left(b^{*}\right)$ di atas, karena siswa menempatkan objek kalimat pada posisi pertama yang seharusnya ditempatkan pada posisi terakhir seperti pada perbaikan kalimat di atas. 
6. Kesalahan Penempatan Kata Kerja Pada Kalimat Tanya yang Menggunakan Kata Tanya (Bestimmungsfragen)

Pembentukan kalimat tanya bahasa Jerman yang menggunakan kata tanya (Bestimmungsfragen) berbeda dengan kalimat tanya yang tidak menggunakan kata tanya (Eintscheidungsfragen). Kesalahan yang sering dilakukan siswa ketika membentuk kalimat tanya yang menggunakan kata tanya (Bestimmungsfragen) yaitu penempatan kata kerjanya. Di bawah ini merupakan contoh kesalahan penempatan kata kerja pada kalimat tanya yang menggunakan kata tanya (Bestimmungsfragen) yang dilakukan siswa dalam menyusun kalimat tanya bahasa Jerman.

a. gehen-warum- nicht-ihr?

Dalam data: *geht ihr nicht warum?

Seharusnya: Warum geht ihr nicht?

b. du-wo-kaufen- den Füller?

Dalam data: *wo du kaufst den Füller?

Seharusnya: Wo kaufst du den Füller?

c. ein Buch-kaufen wann?

Dalam data: *wann Sie kaufen ein Buch?

Seharusnya: Wann kaufen Sie ein Buch?

Kesalahan penempatan kata kerja yang dilakukan siswa pada kalimat $\left(\mathrm{a}^{*}\right)$ karena siswa menyusun kalimat tanya yang menggunakan kata tanya

(Bestimmungsfragen) dengan menempatkan kata kerja pada posisi pertama, sedangkan pada kalimat $\left(b^{*}\right)$ dan $\left(c^{*}\right)$ siswa melakukan kesalahan karena menempatkan kata kerja pada posisi ketiga. Aturan struktur kalimat tanya bahasa Jerman yang menggunakan kata tanya (Bestimmungsfragen), maka kata kerja selalu berada pada posisi kedua atau ditempatkan setelah kata tanya seperti pada perbaikan kalimat di atas.

\section{Kesalahan Penempatan}

Possesivpronomen

Possesivpronmen merupakan kata ganti kepunyaan yang menerangkan kepemilikan seseorang dan possesivpronmen berada sebelum kata benda. Di bawah ini merupakan contoh kesalahan penempatan possesivpronmen dalam menyusun kalimat tanya bahasa Jerman.

a. deine- sein- wie gro $\beta$ - Familie?

Dalam data: *wie gro $\beta$ deine sein Familie?

Seharusnya: Wie gro $\beta$ ist deine Familie?

b. wie-deine-heißen Mutter?

Dalam data: *wie deine heißen Mutter?

Seharusnya: Wie heißen deine Mutter?

Kesalahan penempatan possesivpronmen yang dilakukan siswa pada kalimat $\left(\mathrm{a}^{*}\right)$ dan $\left(b^{*}\right)$ di atas, karena siswa menempatkan possesivpronmen mendahului kata kerja dan tidak berdekatan dengan kata benda. Aturan struktur bahasa Jerman possesivpronmen selalu mengikuti kata benda.

\section{Kalimat Perintah Bahasa Jerman}

\section{(Imperativsatz)}

\section{Kesalahan Konjugasi Kata Kerja}

Kata kerja dalam kalimat perintah mengalami perubahan pada kalimat perintah Du-form dan Ihr-form. Berbeda dengan perubahan konjugasi kata kerja pada umumnya pada kalimat perintah Du-form cara mengubahnya dengan memperhatikan konjugasi (du) tanpa st/umlaut+ (e), sedangkan pada kalimat perintah Ihr-form dengan cara stamm kata kerja $+(\mathrm{t})$ perubahan kata kerja tersebut mengakibatkan sering terjadi kesalahan dalam. Berikut ini merupakan contoh kesalahan konjugasi kata kerja yang dilakukan siswa dalam menyusun kalimat perintah bahasa Jerman.

a. mir-das Buch-bringen!

Dalam data: *Bringt mir das Buch! 
Seharusnya: Bring mir das Buch!

b. nicht-sprechen- laut!

Dalam data: *Sprecht nicht laut!

Seharusnya: Sprich nicht laut!

c. nicht-sprechen- laut!

Dalam data: *nicht sprechen laut!

Seharusnya: sprecht nicht laut!

d. ins Kino-gehen- nicht!

Dalam data: *Gehst nicht ins Kino!

Seharusnya: Geht nicht ins Kino!

Kalimat di atas merupakan contohcontoh kesalahan yang dilakukan siswa dalam pembentukan kalimat perintah. Pada kalimat $\left(a^{*}\right)$ dan $\left(b^{*}\right)$ merupakan contoh kesalahan konjugasi kata kerja pada kalimat perintah Du-form dan kalimat (c*) dan ( $\left.\mathrm{d}^{*}\right)$ merupakan kesalahan konjugasi kata kerja pada kalimat perintah Ihr-form. Pada contoh kesalahan kalimat yang dilakukan siswa di atas, siswa mengkonjugasi kata kerja dalam kalimat berita dengan konjugasi kata kerja pada umumnya. Seperti yang telah dijelaskan sebelumnya bahwa dalam kalimat perintah Du-form diubah dengan memperhatikan konjugasi (du) tanpa st/umlaut+ (e), sedangkan untuk kalimat perintah Ihr-form diubah dengan cara stamm kata kerja $+(\mathrm{t})$. Perbaikan kalimat di atas sudah sesuai dengan aturan struktur kalimat perintah bahasa Jerman.

\section{Kesalahan Penempatan Kata Kerja}

Penempatan kata kerja pada kalimat perintah berbeda dengan penempatan kata kerja pada kalimat berita atau kalimat tanya bahasa Jerman. Kata kerja pada kalima perintah selalu berada pada posisi pertama atau awal kalimat. Dari hasil kerja siswa ditemukan hampir seluruh siswa melakukan kesalahan dalam penempatan kata kerja. Berikut ini merupakan contoh kesalahan penempatan kata kerja yang dilakukan siswa dalam menyusun kalimat perintah bahasa Jerman.

a. nicht-sprechen- laut!

Dalam data: *nicht sprecht laut!

Seharusnya: Sprich nicht laut!

b. spät-kommen-nicht- bitte!

Dalam data: *nicht kommt spät bitte!

Seharusnya: Kommt nicht spät bitte!

Kesalahan yang dilakukan siswa pada kalimat $\left(a^{*}\right)$ dan $\left(b^{*}\right)$ di atas, karena siswa menyusun kalimat perintah dengan tidak menempatkan kata kerja pada posisi pertama. Pada kalimat $\left(\mathrm{a}^{*}\right)$ dan $\left(\mathrm{b}^{*}\right)$ siswa menempatkan kata kerja pada posisi kedua. Dalam struktur kalimat perintah bahasa Jerman kata kerja selalu berada pada posisi pertama atau awal kalimat seperti pada perbaikan kalimat di atas.

\section{Kesalahan Penempatan Objek}

Kesalahan penempatan objek kalimat merupakan kesalahan sintaksis yang berkaitan dengan urutan penyusunan unsurunsur kalimat, dalam hal ini kesalahan menempatkan unsur objek dalam sebuah kalimat yang benar dan utuh berdasarkan tatabahasa sebuah bahasa. Di bawah ini merupakan contoh kesalahan penempatan objek yang dilakukan siswa dalam menyusun kalimat perintah bahasa Jerman.

a. schnell-lesen-den Roman!

Dalam data: *den Roman lest schnell!

Seharusnya: Lest schnell den Roman!

b. Ins Kino-gehen- nicht!

Dalam data: * Geh ins Kino nicht!

Seharusnya: Geh nicht ins Kino!

Kesalahan yang terjadi pada penempatan objek kalimat $\left(a^{*}\right)$ di atas, karena siswa menempatkan objek kalimat pada awal kalimat sehingga objek kalimat di atas diposisikan sebagai subjek kalimat. Sedangkan pada kalimat $\left(b^{*}\right)$ siswa melakukan kesalahan karena siswa 
menempatkan objek kalimat pada posisi kedua. Perbaikan kalimat di atas sudah sesuai dengan aturan struktur kalimat perintah bahasa Jerman.

\section{Kesalahan Penempatan Negasi "Nicht"}

Dari hasil kerja siswa juga banyak ditemukan kesalahan dalam menempatkan kata nicht. Berikut ini merupakan contoh kesalahan penempatan kata nicht yang dilakukan siswa dalam menyusun kalimat perintah bahasa Jerman.

a. ins Kino-gehen- nicht!

Dalam data: *Nicht geht ins Kino!

Seharusnya: Geht nicht ins Kino!

b. spät- kommen-nicht-bitte!

Dalam data: *nicht kommt spät bitte!

Seharusnya: Kommt nicht spät bitte!

Kesalahan-kesalahan yang dilakukan siswa dalam menempatkan kata nicht pada kalimat $\left(\mathrm{a}^{*}\right)$ dan $\left(\mathrm{b}^{*}\right)$ di atas, karena siswa menempatkan kata nicht sebelum kata kerja. Perbaikan kalimat di atas sudah sesuai dengan aturan kalimat bahasa Jerman.

\section{KESIMPULAN}

Berdasarkan pembahasan sebelumnya dapat disimpulkan bahwa masih sangat banyak siswa melakukan kesalahan dalam menyusun kalimat berita, kalimat tanya dan kalimat perintah bahasa Jerman. Secara umum kesalahan yang dilakukan siswa dalam menyusun kalimat berita adalah $33.03 \%$ dan berada pada kategori cukup tinggi, kesalahan kalimat tanya adalah $42.55 \%$ dan berada pada katogori tinggi, sedangkan kesalahan yang dilakukan siswa dalam menyusun kalimat perintah adalah $49.52 \%$ dan berada pada kategori tinggi. Dari gambaran persentase kesalahan di atas terlihat bahwa siswa paling banyak melakukan kesalahan pada penyusunan kalimat perintah, kemudian pada kalimat tanya dan kesalahan siswa yang paling sedikit pada tes menyusun kalimat berita bahasa Jerman.

\section{REFERENSI}

Arikunto, Suharsimi. (2013). Prosedur Penelitian Suatu Pendekatan Praktik. Jakarta: Rineka Cipta.

Aruan, Linda. (2012). Analisis Kesalahan Kalimat Bahasa Jerman Dengan Menggunakan Baumdiagramm Oleh Mahasiswa Bahasa Jerman (Studi Kasus Pada Mata Kuliah Lingustik: Syntax). Jurnal. Unimed.ac.id. Diunduh pada tanggal 17 Februari 2017, pukul 22.00.

Azis, Abdul. (2007). Analisis Kesalahan Berbahasa. Makassar: Badan Penerbit UNM.

Chaer, Abdul. (2007). Linguistik Umum. Jakarta: Rineka Cipta.

Hastuti, Sri. (2003). Sekitar Analisis Kesalahan Berbahasa Indonesia. Yogyakarta: Gema Widya.

Indihadi, Dian. (2010). Pembinaan Bahasa Indonesia Sebagai Bahasa Kedua.http://file.upi.edu.Diunduh pada tanggal 15 Februari 2017, pukul 10.30 .

Jawa, Rosalina Imelda. (2013). Analisis Kesalahan Menyusun Kalimat Berita Bahasa Jerman Siswa Jurusan Bahasa SMAN 2 Nubatukan Kab. Lembaga pro. NTT. Skripsi. FBS Universitas Negeri Makassar.

JUFRI, J. (2007). Metode Penelitian Bahasa, Sastra dan Budaya.

Jufri, J. (2007). Metode Penelitian Bahasa. Sastra dan Budaya.

JUFRI, J. (2017). Strategi Pembelajaran Bahasa.

Junus, Andi Muhammad dan Andi Fatimah Junus. (2010). Analisis Kesalahan 
Berbahasa. Makassar: Badan Penerbit UNM.

Kridalaksana, Harimurti. (2008). Kamus Linguistik. Jakarta: Gramedia Pustaka Umum.

Magfirunnisa, Fitri. (2011). Analisis Kesalahan Bahasa Jerman Siswa Kelas XI IPA 3 SMAN 10 Makassar. Skripsi. FBS Universitas Negeri Makassar.

Mantasiah, R. (2018, June). Pay It Forward Model in Foreign Language Learning to Increase Student's Self Efficacy and Academic Motivation. In Journal of Physics: Conference Series (Vol. 1028, No. 1, p. 012178). IOP Publishing.

Mantasiah, R., Juffri, J., \& Yusri, Y. (2017).

Keefektifan Model Pembelajaran Jaring Laba-Laba (Webbed) dalam Keterampilan Menulis Karangan Sederhana Bahasa Jerman. Indonesian Journal of Educational Studies, 20(2).

Nurhadi. (1995). Tata Bahasa Pendidikan. Semarang: Semarang Press.

Parera, Daniel. (1987). Linguistik Edukasional: Pendekatan, Konsep dan Teori. Jakarta: Erlangga.

Pateda, Mansoer. (1989). Analisis Kesalahan. Ende: Nusa Indah.

Purwanto, M. Ngalim. (1991). Prinsipprinsip dan Teknik Evaluasi Pengajaran. Bandung: Remaja Rosdakarya.

Putrayasa, I. B. (2010). Jenis Kalimat dalam Bahasa Indonesia. Bandung: Refika Aditama.

Qalbi, U. N., Mantasiah, R., Jufri, J., \& Yusri, Y. (2017). Efektivitas Model Pembelajaran Kooperatif Tipe Teams Games Tournaments dalam Keterampilan Menulis Bahasa Jerman Siswa Kelas XII IPA SMA Negeri 1
Bontonompo Kabupaten Gowa. Indonesian Journal of Educational Studies, 20(1).

Qudus, M., \& Yusri, Y. (2017). Keefektifan Penggunaan Metode Audio Lingual dalam Pembelajaran Kemampuan Menyimak Bahasa Jerman. Indonesian Journal of Educational Studies, 20(2).

Saadiah, Siti. (1996). Kemampuan menyusun Kalimat Bahasa Jerman Siswa Kelas III A3 SMU Negeri 159 Sungguminasa Kabupaten Gowa. Skripsi. Ujung Pandang: FPBS Institut Keguruan dan Ilmu Pendidikan Ujung Pandang.

Setyawati, Nanik. (2010). Analisis Kesalahan

Berbahasa Indonesia Teori dan

Praktik. Surakarta: Yuma Pustaka.

Sudjana. (2008). Metode Statistik. Jakarta: Bina Aksara.

Tarigan, Djago dan Lilis Siti Sulistyaningsih. (1996.) Analisis Kesalahan Berbahasa. Jakarta: Proyek Penataran Guru SLTP Setara D-III.

Tarigan, H. Guntur dan Djago Tarigan. (2011). Pengajaran Analisis Kesalahan Berbahasa. Bandung: Angkasa.

Tarigan, H. Guntur. (2009). Pengajaran Sintaksis. Bandung: Angkasa.s

Trianto. (2011). Pengantar Penelitian Pendidikan Bagi Pengembangan Profesi dan Tenaga Kependidikan. Jakarta: Kencana.

Yusri, Y. (2016). Kesalahan Pembentukan Komposita Nomina Dalam Bahasa Jerman Oleh Mahasiswa Program Studi Pendidikan Bahasa Jerman Fakultas Bahasa Dan Sastra Universitas Negeri Makassar. Jurnal Nalar Pendidikan, 4(1). 